\title{
INFORMATION AND COMMUNICATION \\ TECHNOLOGY FOR THE RURAL DEVELOPMENT IN NEPAL
}

\author{
Suman Kharel*
}

\begin{abstract}
The present article describes the significance of Information and Communication Technology (ICT) for the rural development. It is based on the perception survey about ICT, suggesting that ICT can be very beneficial and powerful tool for facilitating rural development, particularly in the sectors of e-commerce, e-health, e-government services and the most important e-education, training, information and expertise exchange, experience sharing, communication and society engagement. Overall, ICT is an effective tool for the different dimension of rural development.
\end{abstract}

Keywords: ICT, rural development, e-commerce, e-government, e-health, e-education.

\section{INTRODUCTION}

Information and Communication Technology (ICT) refers to the broad range of hardware, software, network infrastructure and media that enable the processing, storage and sharing of information and communication both among humans and computers, locally and globally. ICT is a merger of computing and telecommunication technologies for information acquisition, retrieval, and dissemination. Rural Development forms an important agenda of the Government. However, the application of ICT in the Rural Development sector has been relatively slow. The main reasons for this are poor ICT infrastructure in rural areas, poor ICT awareness among agency officials working in rural areas.

ICTs can play a significant role in combating rural and urban poverty and fostering sustainable development through creating information rich societies and supporting livelihoods. If ICTs are appropriately deployed and realize the differential needs of urban and rural people, they can become powerful tools of economic, social and political empowerment. The problem - lower living standards and less opportunities in rural areas,

* Mr. Kharel is a Lecturer, Central Department of Rural Development, Kirtipur, TU. 
which leads to lower competitiveness and, therefore, willingness to leave the area for urban places becomes more significant.

\section{Uses of ICT}

ICT has an important prominent role in knowledge due to its changeable ability and its capability to gathering information and making relationship among farmers. This includes the use of computers, internet, geographical information systems, mobile phones, as well as traditional media such as radio or TV. Although it is a relatively new phenomenon, evidence of the contribution of ICT to rural development and poverty alleviation is becoming increasingly available. ICT has significant roles in various sectors, for example, agriculture, education, economic development, employment e-governance, capacity development and empowerment, service delivery mechanism, health, climate change and disaster management.

The vast majority of poor people lives in rural areas and derives their livelihoods directly or indirectly from agriculture (MOF,2018). Increasing the efficiency, productivity and sustainability of small-scale farms is an area where ICT can make a significant contribution. Farming involves risks and uncertainties, with farmers facing many threats from poor soils, drought, erosion and pests. ICTs can deliver useful information to farmers about agriculture like crop care and animal husbandry, fertilizer and feedstock inputs, pest control, seed sourcing and market prices.

Moreover, appropriate use of ICTs in the classroom fosters critical, integrative and contextual teaching and learning; develops information literacy (the ability to locate, evaluate and use information). Thus, it improves the overall efficiency of the delivery of education in schools and educational management institutions at the national, state/provincial and community level. The use of ICTs in education aims to improve the quality of teaching and learning as well as democratize the access to education. The ICT has a vital role in connecting the rural community to outside world for exchange of information, a basic necessity for economic development. Effective use of ICT can demolish geographical boundaries and can bring rural communities closer to global economic systems and be of meaningful help to the underprivileged.

Poor people in rural localities have lack of opportunities for employment because they often do not have access to information about them. One use of ICTs is to provide on-line services for job placement through electronic labor exchanges in public employment service or other 
placement agencies. The poverty can be adequately addressed by effective use of e-governance and ICT application in environmental management. Improved governance by using ICT can have direct impact in reducing poverty and improving the environment. ICT can contribute in a large way in making government processes more efficient and transparent by encouraging communication and information sharing among rural and marginalized people. Communities and farmer organizations can be helped through the use of ICTs to strengthen their own capacities and better represent their constituencies when negotiating input and output prices, land claims, resource rights and infrastructure projects. ICT enables rural communities to interact with other stakeholders, thus reducing social isolation. It widens the perspective of local communities in terms of national or global developments, opens up new business opportunities and allows easier contact with friends and relatives.

A role is also played by ICT in making processes more efficient and transparent. It helps in making laws and land titles more accessible. Global Positioning Systems (GPS) linked to Geographical Information Systems (GIS), digital cameras and internet, help rural communities to document and communicate their situation. Rural communities benefit from better access to credit and rural banking facilities. Recent mobile banking initiatives offer further scope to reduce costs and stimulate local trade. There is a huge gap between information residing in agricultural knowledge centres and rural communities. At local level, multi-stakeholder mechanisms are important to make relevant information accessible to end users. Intermediary organizations have to connect rural communities to available knowledge. Users will increasingly want tailor-made, quality answers to their questions. The type of ICT used by local communities is subject to rapid change. However, broadband internet access is seen as central for societal innovation because storing of large datasets and live communication requires good connectivity. Until recently, connectivity in rural areas was limited to slow dial-up lines. Satellite connections now make broadband access possible in remote areas. Use of mobile phones has seen an enormous increase in recent years. Nevertheless, big differences still exist in broadband access between developed and developing countries. New generation mobile phone networks, will provide high speed internet services at sharply reduced costs, thereby dramatically increasing internet coverage in rural areas. 
Health care is one of the most promising areas for poverty alleviation. ICTs are being used in India to facilitate remote consultation, diagnosis and treatment. Delivering health care with ICTs enables health care professionals and institutions to address the critical medical needs of rural communities, especially those in remote locations and those that lack qualified medical personnel and services. Natural calamities or Disaster is unpredictable and can occur at any place irrespective of the developed, developing or underdeveloped country. Severe natural disaster leads to massive destruction of properties and even loss of human lives- effect of which remains as a scar for a long time. It is experienced that a large scale natural calamity impacts more severely to the developing or least developed countries than the developed one. Devastation of 2004 Tsunami at Indian coastal regions or $2015 \mathrm{Nepal}$ earthquake are some of the examples which tremble the world. It is observed that rural areas are mostly affected than urban areas in natural disaster mainly due to poor transportation and communication facility. In relation to natural disaster for some cases like cyclone, flood, tsunami, volcanic eruption etc. an early warning system can be setup using remote sensing technology. An earlier forecast helps people for preparedness and to take safe shelter.

This may save a lot of lives and properties from destruction. As examples tsunami warning facility in Japan, Indonesia; cyclone warning facility of Cuba, Mexico, USA have brought life loss figure to single digit even zero. Proper use of ICT tools helps to build knowledge warehouses and data warehousing techniques. Those can facilitate planning and policy decisions for preparedness in right time, quick response and recovery at all levels. Communication system is largely affected by natural disaster which makes the situation worse. GIS based system is governed by satellite and can easily identify the location of any person having the system (May be mobile phone) and stuck in the disaster. GIS with GPS have been found useful in 2013 sudden flood in Uttarakh and, 2014 flood in Kashmir and even in $2015 \mathrm{Nepal}$ earthquake. Remote sensing technique and satellite data may be useful for measuring the ground water situation, which provides a early warning of draught situation. Plan and strategies for relief work for the inhabitants and farmers like well-digging, setting up submersible pump, choosing crop which can grow in less irrigation etc. can be started. Setting up of earthquake sensor can provide a warning for volcanic eruption (ICIMOD,2016). 
The role of ICTs under climate change situation can be explored based on the linkages that exist between ICTs as a system component and its ability to withstand and its ability to recover and to change under changing climatic conditions. ICTs can help strengthen the physical preparedness of livelihood systems for climate change related events through applications such as geographic information systems (GIS), and positioning and modelling applications. ICTs can also strengthen institutions and organizations needed for the system to withstand the occurrence of climatic events, including the support of social networks and the facilitation of coordinated action. For example, ICTs can strengthen social networks through enhanced communication within those networks; Communication increases the network bonds by building trust and a sharing of norms and values.

ICTs can enable access to the set of resources in the event of climate change related shocks or disturbances. ICTs provide access to relevant data and information that is first processed at an individual level, then facilitate communication and interaction between a wide range of stakeholders, and ultimately enable cooperation, which can translate into adaptive actions being implemented with the participation of a wide range of stakeholders. In the Philippines SMS is being used for citizen engagement campaigns that seek to reduce air pollution while encouraging citizen participation, suggesting the potential of these tools to foster environmental action and raise policy awareness. In cases such as this, ICTs can play a role from accessing relevant data and awareness on environmental issues at the individual level, to enabling communication and interaction using mobile telephony, to fostering cooperation with wider networks of stakeholders towards action, through social networking tools and the strengthening of participatory processes.

\section{Challenges of ICT in Rural Development}

Undoubtedly, ICT has offered a great deal of opportunities for the teeming beneficiaries, but not without salient hiccups, which makes it impossible for the rural populace to benefit. More striking is the backwardness of the developing countries, which trickles down to the rural dwellers and development. According to the World Bank report on the developing countries, it is clear that the south Asian countries are at the lowest ebb in terms of general development, compared to their counterparts in the developed countries of the world. To explain this down-turn, it is 
important to state that the developing countries need to put their house together to catch up with the developed countries, considering the myriad of obstacles that require urgent attention (World Bank,2011).

Nworgu (2008) succinctly chronicles the ills in the developing countries which have left them copiously at the divide thus: There are several obstacles on the way of less developed countries joining the rest of the world in reaping the abundant benefits of the present information age. Such problems include lack of security in safeguarding inequity; lack of awareness of the need for ICTs use, high cost of internet browsing; fear of unemployment due largely to undiversified economy; low level of professionalism and lack of strong regulatory body. Corruption is a worldwide phenomenon, but its negative effects on the socioeconomic and political development of any nation is felt more in the less developed countries of the world. As a matter of fact, literacy has continued to be a major setback to the growth of ICT in developing countries like Nepal (MOF,2018). The most of the rural peoples are illiterates and do not have the well withal to understand the use of ICTs for accessing information that will no doubt, enhance their lives. Some of the literates are so poor that they cannot afford any of the ICT facilities. Jeno, et al (2008) agree with the above and explain that more than 850 million people in developing countries are excluded from a wide range of information and knowledge, with the rural poor in particular remaining isolated from both traditional media and new information and communication technologies which would improve livelihood.

\section{REVIEW OF LITERATURE}

It is evident that the whole world faces economic and digital divide among rural and urban areas Western world, e.g. North American countries and Western Europe, face this problem to slightly less extent than the developing world as they have started to address the issue already few decades ago. A big focus on solving the problem of differences of living standards of population in rural and urban areas was devoted to delivering ICT to rural areas. One part of the initiative was to deliver and maintain proper ICT infrastructure (e.g. telecommunication services, broadband etc.) and another; even more important part was to create awareness of the opportunities provided by proper ICT infrastructure to facilitate the adoption and daily use of the newly available services (Firdhous Dsman \& Suhaidi, 2010). 
ICT is a compound or generic term that envelope all the modern improvements in the area of communication (Michael \& Iwokwagh, 2007). It can also be described as a revolutionary advancement in communication, possessing possibilities far too numerous to count. ICT creates a next door effect whereby distance is completely exterminated and far reaching possibilities are brought to our reach (Asadu, 2007). The Internet, for example, is garnering an industry of its own with a lot of resources accruing to and from it. Rodney (2005) seethe internet as a potentially powerful vehicle to mitigate and ultimately change social dynamics, an empowering and engaging means for personal exploration and expression, and a medium that enables one to one communication. The Internet does not only allow one to one communication but one many, many-many etc. Awake (2009) observes that from cell phones to computers to television, technology has found its way into every corner of the world even crossing the divide between the rich and poor and has become a part of life for many.

Empirically, Nepal stands fifth in ICT development among the SAARC countries according to measuring the Information Society Report published by International Telecommunication Union (ITU) in June 2017.The study was done on the basis of ICT readiness, i.e. infrastructures and reach of IT, ICT usage and ICT capability. According to the same report, Iceland is the most developed country in the field of ICT with 8.98 score on the chart. Similarly, Korea stands second with 8.85 . The third, fourth and fifth places are taken by Switzerland, Denmark, and the UK respectively with the scores of 8.74, 8.71 and 8.65.Among 176 countries taken for the study, Nepal stands at 140th position. Among the SAARC countries, Maldives stands at 85 th position, Sri Lanka at 117th position, Bhutan at 129th position and India at 134th position. Bangladesh, Pakistan, and Afghanistan fall behind Nepal on this list standing at 147th, 148th and 159th position respectively (ITU, 2017).

Throughout the literature there exists a huge gap of living standards among population living in urban areas and rural areas. The economic and digital divide leads rural population to much more disadvantaged situation than the ones living in urban areas. This is a global problem, slightly less evident in North America and Western Europe, very evident in the developing world like Nepal. These differences in living standards force the population to move to urban areas in search for opportunities of better lives. 


\section{OBJECTIVE}

The objective of this study is to analyze present status of ICT in Nepal by exploring the potential benefit of ICT in different sectors and solutions to reduce the economic and digital divide among population in rural and urban areas.

\section{METHODOLOGY}

The papers based on both primary (a perception survey of 200 people from various parts of Nepal including IT experts, students, teachers, university professors, farmers, business people, traders, people going to foreign employment, politicians, civil servants) and secondary sources of data (e.g., the 2014 Nepal Ageing Survey) in order to understand the status of ICT in rural development in Nepal.

\section{ANALYSIS}

There is gradual improvement in the field of information and communication (MOF, 2018). The major means of information and communication of Nepal are given below.

Television is the most effective and informative audio-visual media. News, information and varieties of programs are being regularly broadcasted for 24hours through four channels: National Channel from Nepal Television, NTV Plus, News Channel and Kolhapur Channel. The television has set up its transmission centers in 19 different places and has provided the services through geo-surface transmission.

The access to national broadcast of Nepal Television has 72.5 percent of the population 52 percent of the geographical reach. The access to NTV Plus has 42percent of the population and 30 percent of geographical reach. Similarly, the access to Nepal Television is nationwide and to 146 other countries through the satellite. Apart from this, there are various television broadcasting services including online television services in Nepal.

As shown in Table 1, nationally, 51.0 percent households had access to this facility. Regarding to the province, the highest proportion 90.2 percent households of Kathmandu Valley and the lowest proportion 25.5 percent households of Province No. 7 has access to this TV facility.

Ecologically, the higher proportion 53.2 percent households of Terai region has access to this facility and followed by Hill (51.7 percent) 
and Mountain (29.0 percent). Likewise, 61.0 percent households of urban and 30.7 percent households of rural area have this facility.

The Nepal Ageing Survey 2014 (MoHP, 2019) collected information on some ICT related household possessions (TV, Radio, Telephone, Mobile, Phone, computer and Internet).

Table 1: Percentage Distribution of Households with Access to Some ICT Related Facilities

\begin{tabular}{|c|c|c|c|c|c|c|c|}
\hline $\begin{array}{l}\text { Some Selected } \\
\text { Background } \\
\text { Characteristics }\end{array}$ & $P$ & 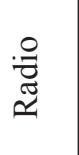 & $\frac{\frac{0}{0}}{\frac{0}{0}}$ & 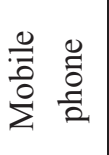 & 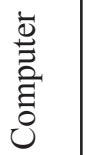 & 离 & $\begin{array}{l}\text { Total } \\
\mathrm{N}\end{array}$ \\
\hline \multicolumn{8}{|l|}{ Place of Residence } \\
\hline Urban & 61.0 & 39.9 & 19.3 & 84.4 & 16.3 & 15.3 & 3160 \\
\hline Rural & 30.7 & 35.8 & 4.2 & 76.1 & 3.3 & 5.3 & 4040 \\
\hline \multicolumn{8}{|l|}{ Ecological Region } \\
\hline Mountain & 29.0 & 49.8 & 10.0 & 72.3 & 2.9 & 3.8 & 480 \\
\hline Hill & 51.7 & 44.9 & 20.6 & 82.1 & 16.7 & 15.6 & 3360 \\
\hline Terai & 53.4 & 30.6 & 8.6 & 82.5 & 8.6 & 9.6 & 3360 \\
\hline \multicolumn{8}{|l|}{ Province } \\
\hline Province No.1 & 57.7 & 44.6 & 12.2 & 83.8 & 10.5 & 12.9 & 1320 \\
\hline Province No.2 & 43.1 & 18.1 & 3.8 & 79.0 & 4.1 & 7.3 & 1240 \\
\hline Province No.3 & 45.7 & 45.3 & 11.3 & 81.9 & 8.5 & 10.3 & 860 \\
\hline Province No.4 & 60.0 & 43.4 & 13.0 & 85.8 & 15.8 & 13.8 & 760 \\
\hline Province No.5 & 46.5 & 36.6 & 9.3 & 81.3 & 7.7 & 6.6 & 1180 \\
\hline Province No.6 & 19.8 & 45.8 & 5.5 & 70.5 & 3.3 & 5.5 & 400 \\
\hline Province No.7 & 25.5 & 44.5 & 10.0 & 73.4 & 4.5 & 5.6 & 620 \\
\hline Kathmandu Valley & 90.2 & 42.8 & 52.7 & 90.5 & 42.7 & 33.4 & 820 \\
\hline Nepal & 51.0 & 38.5 & 14.3 & 81.7 & 12.0 & 12.0 & 7200 \\
\hline
\end{tabular}

Source: Nepal Ageing Survey, 2014

Radio is the most popular, effective and informative audio media. Speaking about news, entertainment and awareness programs, Radio Nepal has been broadcasting in total 21 languages including 8 languages through central broadcasting station. Radio Nepal has the access to 87 percent of population and 90percent of geographical area. Radio Nepal is broadcasting its services by establishing its structure in Central level, Province level and Local levels. Apart from this, there are various FM radios services including online services in Nepal.

Nationally it is seen that 38.5 percent households had access to this facility. Regarding to province, the proportion of households having access 
to this facility ranges from lowest 18.1 in Province No. 2 to highest 44.6 percent in Province No. Ecologically, the higher proportion 49.8 percent households of Mountain region has access to this facility and followed by Hill (49.8 percent) and Terai (30.6 percent). Likewise, 39.9 percent households of urban and 35.8 percent households of rural area had this facility.

Telephone is the most common and easiest communication means. Due to the services provided through new and advanced technology in the field of telecommunication, the number of telecommunication service provider and service users have been increasing for last 30 years. The number of telephone users have been 38 million 160 thousand 142 and its density has reached to 130.3 percent. The density of telephone users have been projected on the basis of the population of 2018. As shown in Table 1, it is observed that only 14.3 percent households have access to this facility nationally. Provincially, 52.7 percent households of Kathmandu valley had access to this facility but households of remaining each province had this facility ranges from the lowest 3.8 percent in Province No. 2 to the highest 13.0 percent in Province No. 4. Ecologically, 20.6 percent households of Hill had access to this facility. But only 10.0 percent households of Mountain and 8.6 percent households of Terai region have this facility. Likewise, 19.3 percent of Urban households and 4.2 percent of Rural households had this facility.

Mobile phone is another most common and easiest modern communication means. The number of mobile phone users, basic telephone users (PSTN), and Global Mobile Personal Communication by Satellite (GMPCS) has been 37 million 297thousand 727, 860 thousand 673 and 1 thousand 742 respectively. The access of mobile services is in all 77 districts and has the access to 90 percent geographical reach. Likewise, the highly advanced technology based mobile services like4G/LTE (Long Term Evolution) have been started in Kathmandu Valley and Pokhara. Nationally, it is observed that 81.7 percent households have access to this facility. Regarding to the provinces, 90.5 percent households of Kathmandu valley had access to this facility and it is followed by other provinces which had more than 70 percent of Mobile users. Ecologically, 82.5 percent households of Terai, 82.1 percent households of Hill and 73.2 percent household of Mountain had access to this facility. Likewise, 84.4 per cent of Urban households and 76.1 per cent of Rural households had this facility. 
By caste/ethnic category, more than two-third majority of all household members stated that they hold mobile phone.

Computer is an electronic communications network that connects computer networks and organizational computer facilities around the world. It is the basic need for education and all over the working place. Overall, it has observed that 12.0 percent households had access to computer facility. With connection to the provinces, the highest proportion 42.7 percent households of Kathmandu Valley owned this facility, which followed by other provinces that ranges from the lowest 3.3 percent households of Province No. 6 to the highest 15.8 percent in Province No. Ecologically, it is observed that 16.7 percent households of Hill, 8.6 percent households of Terai and 2.9 percent households of Mountain owned this facility. Likewise, 16.3 percent households of urban and 3.3 percent households of rural area owned this facility.

There are many benefits of internet and social media in people's lives. Overall, 12.0 percent households of the country had access to Internet facility. It is observed that 33.4 percent households of Kathmandu valley had this facility and others provinces had much more less access to this facility than Kathmandu valley. Ecologically, it is observed that 15.6 per cent households of Hill, 9.6 per cent households of Terai and 3.8 per cent households of Mountain region have access to this Internet facility. Likewise, about 15 percent of Urban households and one in every 20 Rural households (5.3 percent) had this facility.

Electromechanical,InformationSystemandInformationTechnology Security of government integrated data center has been strengthened and the service has been made more reliable and accessible. The construction of the Data Recovery Centre in Hetauda of Makawanpur has been completed for the protection of possible damage of information due to divine disaster and other emergency situation. E-Payment Gateway has been begun to make the payment of the government through online service. National Portal has been upgraded and mobile apps has been prepared. The management of uploading information from the relevant office has been made too. The digital content of Science from Grade 4-7 and Mathematics from Grade 4-9 has been prepared.

A perception survey was conducted among the 200 people living in rural areas of Nepal. The people includes IT experts, students, teachers, university professors, farmers, business people, traders, people going to 
foreign employment, politicians, and civil servants. The output of the result is shown in Table 2.

Table 2: Increase of Effectiveness as a Result of Implemented ICT Initiatives

\begin{tabular}{|c|c|c|}
\hline $\mathbf{S N}$ & Indicator & Agree (\%) \\
\hline 1 & E-Commerce & 88.5 \\
\hline 2 & Filling leisure times of rural youth & 87.5 \\
\hline 3 & Improving postal services & 84.0 \\
\hline 4 & Reducing trips to urban areas & 83.5 \\
\hline 5 & Improving employment opportunity via job searching & 82.0 \\
\hline 6 & Increasing access to telephone & 81.5 \\
\hline 7 & Official registrations by Internet & 80.0 \\
\hline 8 & Reduction in rural-urban migration & 78.0 \\
\hline 9 & Developing crop insurance & 77.5 \\
\hline 10 & Business services & 76.5 \\
\hline 11 & Growth in the number of community businesses & 75.5 \\
\hline 12 & Access to improved health and hygiene information & 73.5 \\
\hline 13 & Access to rural cooperatives information & 72.5 \\
\hline 14 & Increasing value of agricultural sales & 71.5 \\
\hline 15 & Access to information about agricultural markets & 69.0 \\
\hline 16 & Access to information about agricultural Inputs & 67.5 \\
\hline 17 & Access to agricultural weather information & 66.5 \\
\hline 18 & Awareness of events in the country & 65.5 \\
\hline 19 & $\begin{array}{l}\text { Reduction in monetary cost to obtain information and } \\
\text { communication }\end{array}$ & 65.5 \\
\hline 20 & $\begin{array}{l}\text { Reduction in time to obtain information and } \\
\text { communication }\end{array}$ & 64.5 \\
\hline 21 & Changes in household income & 63.0 \\
\hline 22 & $\begin{array}{l}\text { Access to information about agricultural input and output } \\
\text { prices }\end{array}$ & 56.0 \\
\hline
\end{tabular}

Source: Survey Result, 2018.

In this survey altogether 22 questions related to whether there is increase of effectiveness as a result of implemented ICT initiatives were asked. The people ranked lowest (56 percent) in access to information about agricultural input and output prices and highest in ecommerce (88.5 percent) suggesting that ICT is an effective tool to the different dimension of rural development. 


\section{CONCLUSION}

Nepal is still lagging behind in terms of ICTs. With limited capacities and resources, ICT tools (the potential of telecasters for disaster preparedness and response) are emerging as an area of increasing interest to respond to the effects of extreme natural hazards, drought, landslides, floods, and to the impacts of these events on local social systems (e.g., infrastructure, e-governance etc.).The primary cost for establishment and set up of ICT infrastructure has enormous usefulness for the rural people. Though education, agriculture, healthcare etc. are common to all rural areas, but there are several other sections like tourism, banking and finance etc. in which ICT also has a great role to play.

Last but not least, proper implementation of ICT infrastructure and tools/solutions can serve as enabler ofthe development of rural areas, reduce the economic and digital divide and facilitate the development of small micro-finance entrepreneurships (SMEs).

\section{REFERENCES}

Asadu, C.A. (2009). Anatomy of communication for development. Port Harcourt: University of Port Harcourt Press.

Awake, K. (2005). What hope is there for the poor? Journal of Information Engineering and Applications. Retrieved from www.iiste.org Nov.8, 2017. ISSN 2224-5782 .

Firdhous, M., Osman G.\& Suhaidi H. (2013). Cloud computing for rural ICT development: Opportunities and challenges.

ICIMOD (2016). Lessons from Nepal's earthquake for the Indian Himalayas and the gangetic plains. Retrieved Jan 12 from http://lib.icimod. org/record/32068/files/EarthquakeBook.pdf.

ITU (2017). Measuring the Information society report. International Telecommunication Union.

Jeno, E.\& Ehu, E.S. (2008). Information and communication for National development: An overview. In Nwosu, et al, (Eds.). Communication for Health and Sustainable Development in Nigeria. Enugu. RhyceKerex Publishers. 
Michael, B. \& Iwokwagh, S. N. (2007). A philosophical analysis of contemporary issues in information communication technology, globalization and religion. In Mojaye, E. M.V., Salawu, A and Oyewo,O.Y. (Eds.). Ebenezer Soola Conference on Communication Proceedings, 74-79.

MOF (2018). Economic survey. Kathmandu: Author.

MoHP, (2018). Unpublished Nepal ageing survey 2014. Kathmandu: Author.

Nworgu, K. O. \& Didiugwu I.F. (2008). Bridging the digital divide in communications: Appraising the growth of ICTs in Nigeria. International Journal of Communication. No. 8, April, 2008.

Rodney, C. (2005). Modern communication technologies and new world information order. International Journal of Communication. No 2.

World Bank (2011). ICT in agriculture connecting smallholders to knowledge, networks, and institutions. Author. 